IJMS 20 (2), (29-70) (2013)

\title{
CATALYTIC SOCIAL ENTREPRENEURSHIP TO COMBAT DESPERATE POVERTY: A SYSTEMS APPROACH
}

\author{
OSWALD A. J. MASCARENHAS \\ St. Aloysius College (Autonomous) \\ RAM KESAVAN \\ MICHAEL D. BERNACCHI \\ College of Business Administration \\ University of Detroit Mercy
}

Aloysius Institute of Management and Information Technology (AIMIT)

\begin{abstract}
Any credible agenda that seeks to eradicate global poverty must seek to correct the structural injustices and inequities that cause and perpetuate desperate endemic poverty. Such an agenda must aim not merely to aid the poor with grants, welfare and subsidies, but it must primarily seek to enhance the capabilities, skills, access and opportunities of the marginalized to participate on more equitable terms, in the dynamic process of overall economic growth. We apply a systems approach to poverty, the latter itself being a pernicious system. Eradication of global desperate poverty and its unjust structural causes can be done through two concurrent systemsthinking based strategies: (a) micro catalytic social entrepreneurship that leads to catalytic innovations that alleviate poverty, and (b) macro social catalytic political entrepreneurship that radically innovates legislation or designs macro-policy intervention systems that can effectively dismantle existing unjust structures of social injustice and inequities - the causes that perpetuate endemic global poverty. Using the theories of catalytic innovations and the bottom of the pyramid, we focus on solution (a) as being feasible, viable and doable and in the long run having the potential for eradicating global desperate poverty. We also provide two case studies where solution (b) was effectively implemented. The main proposition of the paper is that the use of both micro- and macro- catalyst can help alleviate poverty in the world.
\end{abstract}

Keywords: Micro catalyst, macro catalyst, global poverty, system approach, catalytic innovation, macro-policy intervention. 


\section{Introduction}

The world has been eagerly watching these days to see how individual political activists (e.g., Anna Hazare and his team in India; political activists in Libya, Egypt and Sudan) have been combating deeply ingrained multilayered structural injustices such as corporate fraud, bribery and corruption that ultimately cause and perpetuate desperate poverty among the marginalised billions. In essence we distinguish between two extreme groups in this paper. Those on top of the income pyramid (TOP) are the powerful and those on the bottom of the income pyramid (BOP) are the powerless.

Highly organized and institutionalized corruption and bribery practices are value-destruction chains and cycles; for instance, they siphon billions of dollars to "black-money havens" such as Swiss banks, thus depriving development-focused capital in developing nations. Moreover, they cause brain drain. Demoralized and disillusioned educated youth immigrate to countries that can provide them with meaningful and gainful jobs, thus causing and perpetuating poverty that originates from not retaining homegrown productive skills. This is a clear instance that poverty originates in the structural injustices of a social and political order that incapacitates the BOP from participating in the mainstream economic growth activities (Maxwell, 1999; Scott et al., 2011). In such unethical systems even good-willed targeted programmes of poverty alleviation carry high transaction costs due to the institutional structures that obstruct the delivery of aid and resources to the poor. It has been well documented that there are deep- seated structural injustices and inequities that institutionalize and perpetuate poverty especially in developing nations (Sen, 2000; 2011).

Currently, other causes perpetuating global desperate poverty are emerging. Dictatorial or corrupt governments and corporate tycoons of Myanmar, Libya, Egypt, Haiti, Sudan and India are known for funnelling wealth into private coffers to the detriment of their BOP citizens. The wealthy in such regimes are often fugitives from taxes, thus refusing to contribute to national growth and development. We cannot dismiss these countries as exceptional or irrelevant. This is where governments and many large corporations are corrupt and we find the largest and most intractable pockets of desperate poverty (Andreasen, 1975; 1982; Collier, 2008; Sachs, 2006). 


\section{Structure of Global Endemic Poverty}

The inequalities among us were originally fuelled by natural forces the unequal distribution or endowment of humans in terms of native talent and intelligence, learned skills and committed industriousness, warrior courage and brave perseverance, etc. Fortune did favour the brave and the intelligent, and soon mankind was split into warriors and cowards, chiefs and the subjects, the haves and have-nots, the more able and the less able, leaders and followers, employers and employees and masters and slaves. The gap between these two classes has widened ever since. Some believe we can do nothing about these "original" positions of natural endowments and inheritances. Nozick (1977) called this the natural entitlement theory of justice.

This type of poverty originates in the structural injustices of a social order that incapacitates the poor from participating in the growthgenerating sectors of the market economy and leaves them enslaved in the so-called informal or unorganized sector characterized by low productivity and low income earning capacity. If, therefore, global poverty originates and perpetuates in such unjust structures of a society, then, they must be addressed by macro-level policy interventions that progressively dismantle them via effective social, economic and political reform or revolution (Sobhan, 2005). Andrews and Leigh (2009) observed that extreme income inequalities tend to reduce social mobility (see Figure 1). Hence, to achieve social mobility, income inequalities must be reduced over time.

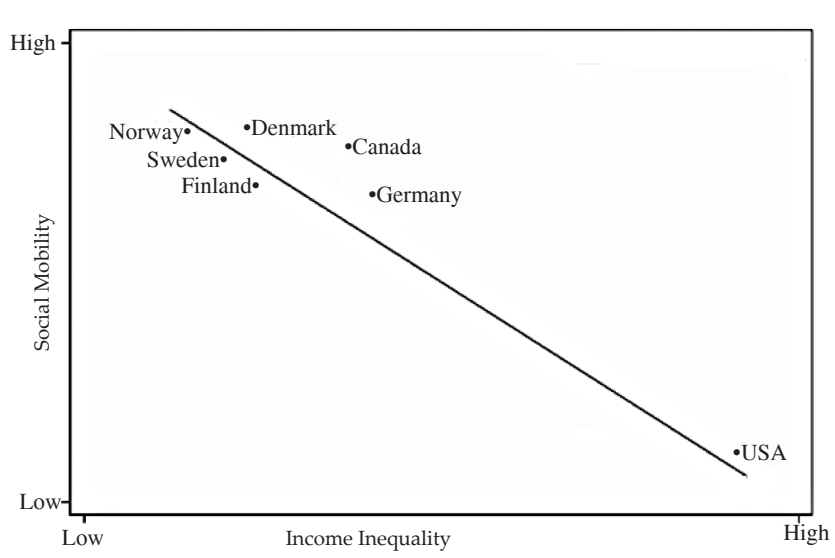

Source. www.equalitytrust.org.uk

Figure 1. Income inequality \& social mobility: An inverse relationship. 


\section{A System's Approach to Global Poverty}

Both natural and man-made sources of endemic global poverty have major consequences on the poor who are mostly wage earners (Collier, 2008; Sachs, 2006; Sobhan, 2005):

1. Inequitable and unequal access to productive agrarian assets such as adequate housing and sanitation, basic food and drinking water amenities, land and water for cultivation, sufficient schooling and health facilities, the job and product markets, and in general, wealth and knowledge.

2. Unequal participation in the market brought about by several related factors such as the neglected rural economy while most developments take place in the urban economy, unjust separation between the owner of the rural land and the actual tiller of the land, exploitative tenancy or lease arrangements to the poor, forced to sell their labour and produce under severely adverse conditions, and thus, progressively reduced sharing of value-added accumulating in rural profits and wealth.

3. Resulting from (a) and (b) low productivity that leads to low wage earnings that leads to low access to educational and technology that, in turn, translates to low wage earnings, low buying power, low access to product markets, deprivation of quality of life, frustration, crime, imprisonment, which in turn perpetuate chronic indebtedness and desperate poverty. This is the phenomenon of perpetuating dynamic and spirally escalating poverty that occurs in ghettos, degraded ghost towns, and certain rural areas of even developed countries like the U.S, emerging and developing countries like India and China, and in the poorest countries of the world (e.g., the poorest 25 countries of the world, many of which are in Africa).

4. Indirectly resulting from (a), (b) and (c), is another pernicious phenomenon of the current decades that aggravates and perpetuates global poverty: The growing disparity in the quality of education, healthcare and housing amenities between the rural poor and the rural rich and between the urban poor and the urban wealthy results in an expanding divide between these population segments, rendering the pinch and pain of desperate poverty even worse (Sobhan, 2005).

\section{Systems Thinking and Poverty}

The word "system" originates from the Greek verb sunisthánai, which originally meant "to cause to stand together." Thus, a system is 
anything (subject, object, property or event) that is made up of two or more interdependent parts. Etymologically speaking a system implies a structure that holds the parts together in a functional whole. A system is a perceived whole whose elements hang together because they continually affect each other over time and operate toward a common purpose.

In this universe, everything is connected to everything else. For instance, a market economy is a system. All products and services offered in that market economy are systems. A business corporation or organization that offers such products and services is a system. A market that absorbs these products and services is a social or economic system. Poverty is a system primarily created either by the market forces or people within the market system.

At its broadest level, systemic thinking encompasses a large and fairly amorphous body of methods, tools and principles, all oriented to looking at the interrelatedness of forces, and seeing them as part of a common process. The field of systems thinking includes cybernetics and chaos theory, gestalt therapy, the work of Gregory Bateson, Russell Ackoff, Eric Trist, Ludwig von Bertallanfy, and the Santa Fe Institute, the "systems dynamics" as developed by Jay Forrester at MIT over the past several decades; and dozens of other techniques for "process mapping" flows of activity at work. All of these diverse approaches have one guiding idea in common; that behaviour of all systems follows certain common principles, the nature of which are being discovered and articulated (Senge, 2006). The behaviour of poverty as a system also follows certain subtle common principles the nature of which we seek to investigate in this paper. According to Senge (2006), our vision remains fragmented, each of us mistaking the pieces for the whole (as did the blind men trying to define the elephant). We may even give up trying to see the whole together and be happy with our reductionistic picture of the world. Thus far, most of our efforts to understand poverty are at best fragmented and reductionistic, and so are our solutions to endemic poverty.

If we reassemble and reorganize the pieces, however, we see connections, interactions and interrelationships between parts and components we have never seen and registered before and eventually we see a larger whole, and understand reality around us better. This is systems thinking. Systems-thinking helps us to destroy our illusion that the world is created of separate and unrelated forces. But a systematic holistic approach to poverty is not forthcoming. The 
hitherto piecemeal, quick-fix solutions to eradicate desperate poverty have been, by and large, mere symptomatic solutions affecting the symptoms of poverty and not its root causes.

Systems-thinking is a conceptual framework, a body of knowledge and tools that has developed over the past fifty years, to identify and explore patterns in reality around, to make the full patterns clear, and to help us see how to change them effectively (Senge, 2006). Like any other discipline, one needs to practise systems thinking as a lifelong process of honing and developing this talent. It is not simply a "subject of study" but a body of techniques, based on some underlying theory or understanding of the world. As we develop this proficiency, our perceptual capacity develops, and we gradually surrender to new ways of looking at our world.

\section{Essential Features of Systems Thinking}

System thinking is a discipline for seeing wholes. It is a framework for seeing interrelationships rather than linear cause-effect chains and things, for seeing processes and patterns of change rather than static snapshots. Systems-thinking is a sensibility for the subtle interconnectedness that gives living systems their unique character. It is a discipline for seeing the "structures" that underlie complex situations, and for discerning high from low leverage change. It is a shift of mind from seeing parts to seeing wholes, from reacting to the present to creating the future, from seeing ourselves as helpless reactors to changing reality to seeing ourselves as active participants in shaping that reality. "The unhealthiness of our world today is in direct proportion to our inability to see it as a whole" (Senge, 2006). The pernicious nature of poverty today is in direct proportion to our inability to see it as a whole.

More specifically, systems-thinking is a way of thinking about, and a language for describing and understanding the forces and interrelationships that shape the behaviour of systems. This discipline helps us to see how to change systems more effectively, and to act more in tune with the larger processes of the natural and economic world. More specifically, systems-thinking is a fundamental shift from linear thinking to circular thinking, from seeing things as static structures or objects to viewing them as processes. The same is true of poverty as a living system; systems thinking must see and seek order from its present chaotic, destabilizing and dehumanizing forces. 
In systems thinking, an important property of a system is its structure. Poverty is a structure of patterned interrelationships brought about by various market elements. We need a language of interrelationships to understand, explain, predict and control the formidable system of poverty as we know it today; via systems-thinking we need to see far beyond the variables and influences that seem to surface and constitute it currently.

In summary, the essence of the discipline of systems thinking lies in the shift of mind along two dimensions (Senge, 2006):

1. Seeing interrelationships rather than linear cause-effect chains in reality;

2. Seeing processes and patterns of change rather than static snapshots of reality.

\section{The Concept of Feedback in Global Endemic Poverty}

An important concept in systems thinking is "feedback." The term means a much broader concept than the positive or negative feedback we receive from our customers, colleagues or bosses. Thus, positive feedback means praise and negative feedback means criticism. For instance, as a cloud amasses, the sky darkens, leaves twist upwards, and we know that it will rain, and it rains. The storm run-off feeds into groundwater miles away and the sky clears by the next day. All these events may be distant in time and space, yet they are connected within the same pattern. Each has an influence on the rest, even though they are invisible to us. We can understand the system of a rainstorm by contemplating the whole, not any individual part of the pattern.

In systems-thinking and systems dynamics, feedback means any reciprocal flow of influence. Positive feedback denotes a selfreinforcing process, and negative feedback represents a selfcorrecting process. The key to seeing reality systemically is seeing circles of influence rather than straight lines. Every circle tells a story. By tracing the flows of reciprocal influence, we can see patterns that repeat themselves, time after time, making situations better or worse. Poverty exists and augments as an important feedback system of reciprocal flows of influence.

Positive feedback or loops are self-reinforcing: e.g., more chickens lead to more eggs, that in turn lead to more chickens, and soon the egg and the chicken population will grow exponentially and out of control. But 
nature provides negative feedbacks or loops that are self-correcting. Self-correcting feedback loops are natural forest fires, landslides, soil erosions, forest disease, forest insects, high temperatures or freezing colds, floods or droughts. We must identify and distinguish between reinforcing and correcting feedback loops of endemic poverty.

\section{The Concept of Delays in Systems Thinking}

Delays occur often in both reinforcing and balancing loops. Delays are points where the chain of influence takes particularly a long time to play out. Delays have enormous influence in a system, frequently accentuating the impact of other forces. Delays occur when the effect of one variable on another takes time. Delays between actions and consequences are everywhere in human systems. Virtually, all feedback processes have some form of delay. We invest now in projects to reap harvest in the future; we hire people today, but it may be months before they are trained and skilled to produce the desired results. We often do not recognize or understand such delays, and hence, we become unstable, and tend to "overshoot", going further than needed to produce a desired result. We overbuild inventory, we overbuild bridges, we overbuild houses and real estate markets, and invariably, there is an eventual shakeout. The most recent subprime mortgage-lending crisis is an overbuilding of real estate markets: we overbuilt houses, we overpriced houses, and we overextended home mortgage credit. The first shakeout was sub-prime lending; the second shakeout was payment defaults; the third shakeout was declining real estate prices; the fourth shakeout was home foreclosure; the fifth shakeout was the collapse of Fannie May and Freddie Mac until the Federal government came to their rescue. Unrecognized delays can lead to instability and breakdowns, especially when the delays are long. The more aggressive we are in our overshooting behaviour, the worse the shakeout crises, often ending with bankruptcy and poverty.

In identifying strategies that can eradicate global poverty there will be system delays between the strategies (causes) for eradicating poverty and the effects (equitable distribution of wealth and opportunity) that follow long thereafter. In reinforcing loops, delays can shake our confidence, because growth does not come quickly as expected. In balancing loops, delays can dramatically change the behaviour of the system (Senge, 2006).

In combating poverty at the local, national and global levels, societies have considered using certain balancing processes (e.g., welfare 
programmes such as social security to sustain retirement; Medicare, Medicaid and other healthcare programmes to ensure healthcare, and subsidizing farmers when the monsoon fails).

\section{Poverty as a Structured System}

Our discussion on systems, structures, systems thinking and the elements of feedback, reinforcing and balancing loops and leverages should enable us to analyse the system and the structure of global endemic poverty as we find it today. As a system, it is made of subjects, objects, properties and events that cause and constitute it. If we seek to eradicate poverty effectively then we must treat it as an integrated pattern of complex interrelationship between, micro and macro, subjects and objects, and properties and events that fuel it. We must address these patterns of relationships together and not piecemeal with any of its particular parts.

Poverty is a subject-object system with unique properties and events. As a system it is caused by:

- $\quad$ Certain subjects (e.g. the producers and consumers; the buyers and sellers; the wealthy and the poor; the governments and the governed) in relation to

- $\quad$ Certain objects (e.g. money, produce, products, services, material needs such as food, water, land, and clean air) in relation to

- Certain properties (e.g. housing, healthcare, education, sanitation, employment) and with

- Certain events (e.g. greed, avarice, selfishness, corporate fraud, corruption and bribery, wars, conquest, despotism, autocracy, invasion, colonization, oppression, and suppression as human events; droughts, famine, tsunami, floods, landslides, earthquakes, as natural disastrous events, and certain quasihuman and market-related phenomena such as depression, recession, and a stagnant economy).

Figure 2 characterizes one such system that we hypothesize as causing systemic poverty. Following systems thinking, Figure 2 captures the dynamic structure that augments global abject poverty in two concentric circles of antecedents and determinants that are the subtle, direct and indirect, effects of current unjust structures of injustices and inequities.

One may identify at least eight circularly connected socio-economic imbalances generated among the wealthy or the Top of the Pyramid (TOP): 
1. TOP's access to quality housing, health \& education.

2. TOP's high productivity skills.

3. TOP's high earning \& buying power.

4. TOP' s high access to market economy.

5. TOP's high access to income \& earnings.

6. TOP's increasing wealth and power.

7. Buying law \& order among the TOP.

8. Low incarceration among the TOP.

Corresponding eight circularly connected socio-economic imbalances were caused among the marginalized poor, the Bottom of the Pyramid (BOP):

1. Low access to housing, health \& education among the BOP.

2. Low productivity skills among the BOP.

3. Low earning \& buying power among the BOP.

4. Low access to market economy by the BOP.

5. Chronic indebtedness among the BOP.

6. Increasing deprivation of the BOP.

7. Theft, crime \& rebellion among the BOP.

8. Imprisonment of the already victimized BOP.

A system's feedback structure generates its dynamics. The most complex behaviours usually arise from interactions or feedbacks among the components of the system, from the multiplicity of positive and negative feedback loops all acting simultaneously, from the complexity of the components themselves, and from the complexity of the environment surrounding it. Figure 2 implies multiple, positive and negative, feedback loops all acting simultaneously, thus generating complexity arising from both the components (e.g. a, b, c, $\ldots, h$ ) and the environment (e.g. A, B, C, .., H).

In systems thinking, feedback is an axiom that states that every influence is both cause and effect. Nothing is ever influenced in just one direction. Reality exists in structures, and structures cause behaviour. Figure 2 captures this phenomenon. Seeing only individual actions and missing the structure underlying our actions, is the root of our linear thinking and powerlessness in understanding complex systems.

Equivalently, a structure of social injustice and inequity that "builds up" to global poverty the pattern of interrelationships among key components of the human history system is sketched in Figure 2. 
Not all structures are visible or conscious; they are built from forced choices (a-b-c-d-e-f-g-h-a) the BOP has to make while the TOP have their structured choices ( A-B-C-D-E-F-G-H - A) over time, consciously or unconsciously. The latter organizations could be many; such as the multinational and transnational organizations following the so-called market logic, great technological advances that follow the science logic, and the great distribution mechanisms that follow the law of supply and demand. A mentality of greater individualism has resulted with diminished communication (e.g., think of most electronic media like the TV, iTunes, iPods, iPhones, mobile phones, Facebook and Twitter that have made us more superficial and mechanistic without depth and serious communication).

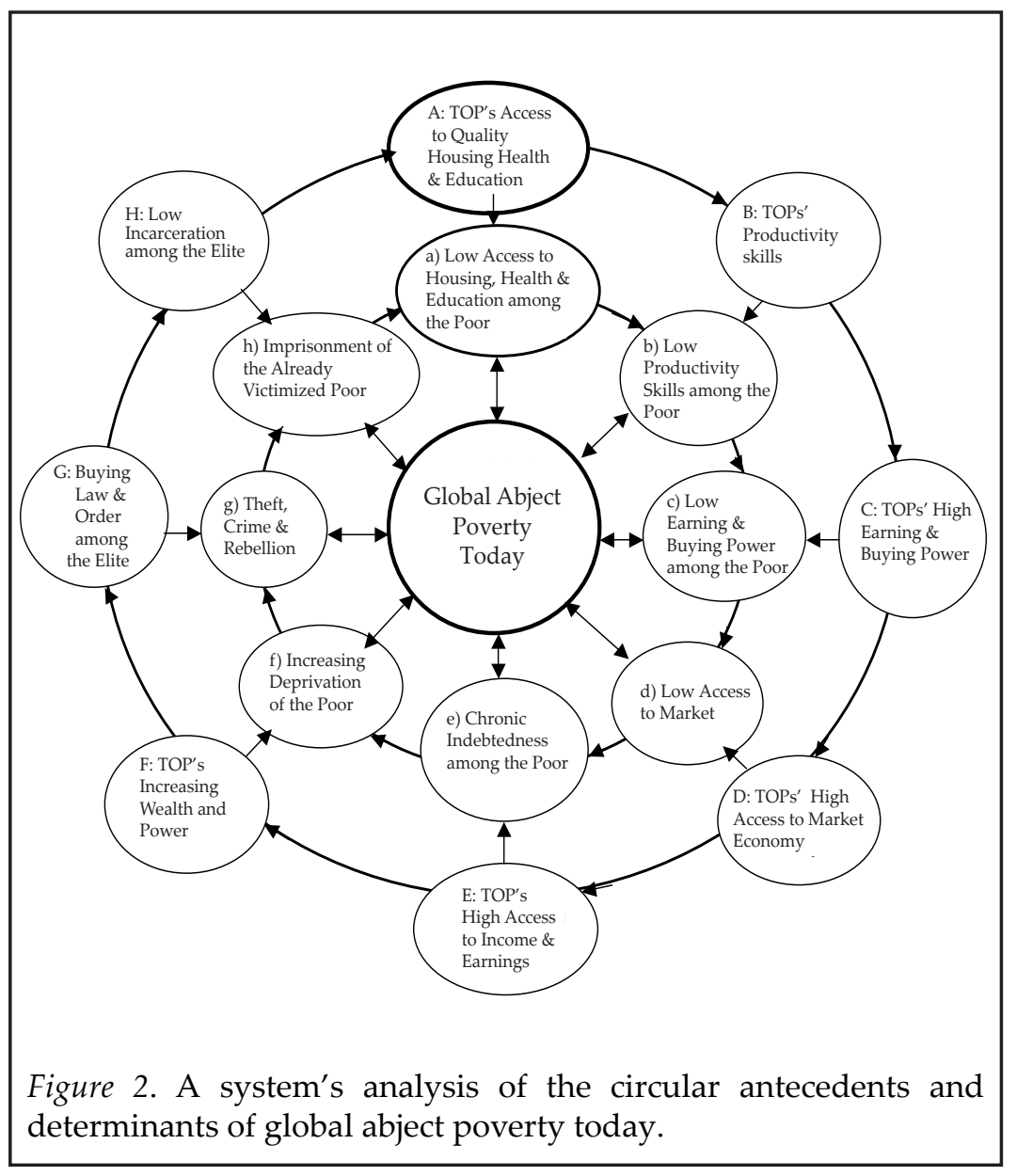


Our paper does not purport to eradicate desperate poverty at the global level that arises from both the theories of natural endowment and unjust structures of injustice and inequities. In fact, against the position held by Nozick (1977), others believe that we can do something about this vicious twofold circle of endemic poverty (Rawls, 2001; Sen, 2000; 2011). Following such classical treatises of distributive and corrective justice and their more recent applications (Mascarenhas, Kesavan \& Bernacchi, 2005; 2008), one could try to reverse this trend by giving the BOP equal opportunity for education and skills-training, for bravery and industriousness, and for commitment and perseverance, so that desperate poverty may be alleviated and eradicated.

This is the mandate of social or distributive justice worth following, but beyond the entrepreneurial scope and purview of this paper. But it has been tried before and reached nowhere close to a cosmic effective solution. Instead, it has resulted in consistent finger-pointing laying massive guilt on the TOP and simultaneously exonerating the BOP-a point of no net returns. In its place, we pursue the path of positive rather than negative thinking, investigating what we could do to alleviate and even eradicate poverty. One such method is catalytic social entrepreneurship that brings about high-quality necessary products and services to the disadvantaged poor at affordable prices. An excellent example of this is the case of Aravind Eye Care (Prahalad, 2011).

\section{Characterizing the Problem of Endemic Poverty}

From a systems view-point, any problem is a "system at unrest" (Ackoff \& Emery, 1972). Table 1 characterizes the intrinsic structure of this global endemic poverty. Mathematically, any problem can be represented by a simple equation such as:

$$
P=f(X, Y)
$$

Where, $\mathrm{X}$ is a vector of endogenous variables that cause the problem internally (in the case of poverty, $a, b, \ldots, h$, as suggested in Figure 2 ) and $Y$ is a vector of external or exogenous variables that cause and determine the problem from the outside (in the case of poverty, $\mathrm{A}, \mathrm{B}, \ldots \mathrm{H}$, as indicated in Figure 2). $\mathrm{X}$ includes internal variables controllable within the problem domain, while $\mathrm{Y}$ is the external "environment" of uncontrollable variables. In systems language, an environment represents another system outside the system under 
consideration (in our case, the internal system of poverty) whose elements (e.g. subjects, objects, properties and events) influence and impact the system under consideration, but whose elements cannot impact the outside system. If it does, then the environment outside the system becomes part of the system.

Other things being equal, when $\mathrm{Y}$ dominates $\mathrm{X}$ ( or $\mathrm{Y}>\mathrm{X}$ ), there is a problem, and the severity of the problem is a function of the nature, level, scope and domain of dominance of $Y$ over $X$. In our case, as long as and to the extent that the external environment $\mathrm{Y}(=\mathrm{A}, \mathrm{B}, \ldots$. , $\mathrm{H})$ dominates and controls the internal environment $\mathrm{X}(=\mathrm{a}, \mathrm{b}, \ldots ., \mathrm{h})$, alleviation and eradication of global desperate poverty could remain an insurmountable challenge.

A problem correctly identified and well formulated is half solved (John Dewey). To solve a problem, you have to get ahead of it and change the determinants of its occurrence. Formulating a problem carefully can help you identify the reasons it is occurring (e.g. antecedents and concomitants). Antecedents are factors and events that precede but influence the problem at hand. Concomitants are factors and events that accompany and influence the problem at hand. Determinants are factors and events that cause (and are necessary or sufficient conditions to) the problem. Consequences are effects and outcomes that are causally connected to the problem or its selected solution (Ackoff \& Emery, 1972). We submit that global endemic poverty situations are local and domestic problems that have international and global antecedents, concomitants, determinants and consequences. All four forces can be reckoned as feedback loops, positive or negative, reinforcing or balancing.

A linear solution may be good enough for simple local poverty problems. We need circular (or non-linear) systems solutions to understand and resolve complex, unstructured and "wicked" (Rittel \& Webber, 1973) problems that global poverty implies. One can treat global desperate poverty as a macro versus micro problem, and each problem type could be addressed with a micro versus macro resolution strategy. Table 1 outlines the resulting $2 \times 2$ quadrants of possibilities.

For instance, treating the global poverty eradication problem (GPEP) as a micro problem would consider global poverty as an individuated problem of choices (e.g. personally willed dependency or mendicancy, and consequently, willed illiteracy and unemployment, willed 
laziness, low esteem, inferiority, and mediocrity). Typical micro strategy solutions to this GDEP problem in Quadrant One are mostly sporadic, discrete and individualized band-aid resolutions such as alms, food aid, food, water and health stamps, housing subsidies, medical insurance, welfare subsidies, and the like meted out to individual households in specific cities and villages of given states or countries.

\section{Table 1}

\section{A Fourfold Structure of the Global Poverty Problem and Resolution Strategies}

Treatment of the Resolutions to the Global Poverty Eradication Problem Global Poverty (GPEP) considered as a:

Eradication Problem (GPEP) as a:

Microstrategy:

[Treat the GPEP as an individualized and personalized choice situation that needs individual and customized, discrete and specific interventions of humanitarianism]

Microproblem: [Global poverty is an individual problem of choices such as willed illiteracy, unemployment, laziness, low esteem, inferiority, mediocrity, dependency, mendicancy, misfortune, fatalism, and destiny]
Sporadic Discrete

Individualized Resolutions:

Piecemeal, disconnected and individualized interventions by corporations, NGOs, philanthropic firms and donors that result in bandaid programmes such as alms, food aid, food stamps, water stamps, health stamps, housing subsidies, medical insurance, welfare subsidies, and the like meted out to individual households in specific cities and villages of given states.

\begin{abstract}
Macrostrategy: [Treat the GPEP as an institutionalized and structural forced choice situation on the poor that needs social, political and international, systematic and continuous interventions of socio-political order reform or revolution]
\end{abstract}

\section{Sporadic Discrete}

Institutionalized Resolutions:

Macro, systematic and continuous policy or project interventions that alleviate but not eradicate global poverty such as all public welfare and social security systems, Medicare and Medicaid systems, agricultural subsidies, electricity, water, and utility subsidies, minimum wage legislations, emergency social security supplements, education grants, welfare or social security payments, tax credits, and other reactive emergency provisions to victims affected by natural disasters. 


\begin{tabular}{|c|c|c|}
\hline $\begin{array}{l}\text { Treatment of the } \\
\text { Global Poverty } \\
\text { Eradication Problem } \\
\text { (GPEP) as a: }\end{array}$ & \multicolumn{2}{|c|}{$\begin{array}{l}\text { Resolutions to the Global Poverty Eradication Problem } \\
\qquad \text { (GPEP) considered as a: }\end{array}$} \\
\hline $\begin{array}{l}\text { Macroproblem: } \\
\text { [Global poverty is } \\
\text { a macro social and } \\
\text { political problem } \\
\text { that originates in the } \\
\text { structural injustices } \\
\text { and inequities of the } \\
\text { socio-political order } \\
\text { (e.g. race-gender-color- } \\
\text { religion-nationality } \\
\text { discrimination) that } \\
\text { disadvantages the poor } \\
\text { from participating in } \\
\text { one's national and } \\
\text { global growth economy } \\
\text { and opportunity] }\end{array}$ & $\begin{array}{l}\text { Systematic Networked } \\
\text { Individualized Resolutions: } \\
\text { Systematic, connected } \\
\text { micro project/policy } \\
\text { interventions (e.g. } \\
\text { catalytic entrepreneurial } \\
\text { interventions such as } \\
\text { Grameen bank micro- } \\
\text { financing, Aravind Eye } \\
\text { Care, FINCA, ...) that } \\
\text { seek to eradicate social } \\
\text { and political structures of } \\
\text { injustice that cause and } \\
\text { perpetuate global poverty } \\
\text { such as: unjust laws, } \\
\text { unjust discrimination, } \\
\text { uneven distribution of } \\
\text { economic opportunity, } \\
\text { unjust property ownership } \\
\text { structures, forced child } \\
\text { labour, sweatshops, bribery, } \\
\text { deception, corporate } \\
\text { fraud and corruption, } \\
\text { excessive profiteering, } \\
\text { misappropriation of } \\
\text { agrarian land, water and } \\
\text { mineral resources for } \\
\text { exorbitant corporate gains, } \\
\text { exploitative tenancy/lease } \\
\text { arrangements, political and } \\
\text { corporate bribery and the } \\
\text { like. }\end{array}$ & $\begin{array}{l}\text { Systematic Networked } \\
\text { Institutionalized Global } \\
\text { Resolutions: } \\
\text { Systematic and continuous } \\
\text { macro policy or macro } \\
\text { project interventions } \\
\text { that not only alleviate } \\
\text { but eradicate global } \\
\text { poverty by dismantling } \\
\text { current oppressive and } \\
\text { suppressive unjust } \\
\text { structures such as uneven } \\
\text { and inequitable access to } \\
\text { productive assets, unequal } \\
\text { capacity to participate } \\
\text { in a growing economy, } \\
\text { undemocratic access } \\
\text { to wealth, knowledge, } \\
\text { education and political } \\
\text { power, illegal buying of } \\
\text { votes, creating rural vote } \\
\text { banks by free distribution } \\
\text { of money and gifts, } \\
\text { massive political lobbies, } \\
\text { money laundering, illegal } \\
\text { political campaigns } \\
\text { and funds solicitation, } \\
\text { structured and forced } \\
\text { unemployment by } \\
\text { automation, robotics, } \\
\text { organizational downsizing, } \\
\text { exporting jobs via } \\
\text { outsourcing, plants } \\
\text { shutdown; thus creating } \\
\text { ghost towns, ghettos, } \\
\text { degraded landscapes, } \\
\text { squalor, destitution, crime } \\
\text { and imprisonment. }\end{array}$ \\
\hline
\end{tabular}

Correspondingly, resolving the micro problem of GPEP via macro strategies (see Quadrant Two) would consider global poverty as an institutionalized and structured forced choice situation on the poor that needs social, political and international, systematic and continuous interventions of socio-political order reform or revolution (such as public welfare and social security systems, Medicare and Medicaid systems, agricultural subsidies, electricity, water, and utility subsidies, minimum wage legislations, emergency social security supplements, and tax credits). 
On the other hand, treating GPEP as a macro problem would consider global poverty as a macro social and political problem that originates in the structural injustices and inequities of the socio-political order (e.g. race-gender-color-religion-nationality discrimination) that progressively disadvantage the poor from participating in one's national and global growth economy and opportunity. Treating GPEP as a macro problem, we may devise either micro or macro strategies to address it. Quadrants Three and Four in Table 1 detail typical solutions under each situation.

\section{Poverty as a Macro Problem with a Micro Strategic Resolution}

Quadrant One and Two solutions have been tried for centuries and have not proved effective in the long-run. Quadrants Three and Four promise better zones for lasting solutions.

Given this discussion, a twofold solution-strategy to global poverty eradication seems to be relevant:

1. A micro approach of individual entrepreneurial catalytic interventions that empower the BOP to circumvent the existing "natural" structures of injustice and inequities by seeking innovative ways for accessing productive assets to the BOP such that they will progressively alleviate, and even eradicate in the long run, forces that cause and perpetuate endemic poverty.

2. A macro approach of social and/or political entrepreneurial catalytic interventions that empower the BOP to progressively dismantle the existing "man-made" cruel structures of injustice and inequities by seeking innovative ways for empowering the BOP to access productive assets such that that they will progressively eradicate causes and factors that generate and perpetuate endemic poverty.

Our paper outlines a systems concept, theory and systems-thinking methodology for effectively planning, designing, creating and implementing strategies (1) and (2). Solution (1) seeks to dismantle the inner vicious circle of global abject property (i.e. the circle a-b-c-de-f-g-h-a in Figure 2), while solution (b) seeks to deal the outer macro circle of exogenously determined vicious circle (i.e. A-B - C - D - E $-\mathrm{F}-\mathrm{G}-\mathrm{H}-\mathrm{A}$ in Figure 2) of global desperate poverty. Given the thrust of this paper on entrepreneurial solutions to GPEP, we focus on solution (b) above or Quadrant Three in Table 1. 
Systematic, connected micro project/policy interventions (e.g. catalytic entrepreneurial interventions such as Grameen bank micro-financing or Aravind Eye) can alleviate, if not always totally eradicate, global poverty. While not dismantling existing and past social and political structures of injustice that cause and perpetuate global poverty (such as unjust laws, unjust discrimination, uneven distribution of economic opportunity, unjust property ownership structures, forced child labour, sweatshops and misappropriation of agrarian land), Quadrant Three solutions seek to empower the BOP to seek self-sufficiency via training and development of people and resources.

\section{Eradicating Global Poverty at the Bottom of the Pyramid}

Ever since Prahalad and Hart (2002) coined the term "bottom of the pyramid", the theory of the bottom of the pyramid (BOP) has been gaining much attention among multinationals and academicians (Prahalad, 2011; Hart, 2005; Hart \& Christensen, 2002; Prahalad, 2009; Prahalad \& Hammond, 2002). The BOP represents billions of the world's poorest who live on less than two dollars a day, amidst their lack of basic amenities such as food, water, shelter, sanitation, clothing, privacy, healthcare, and education, resulting in hunger, thirst, sickness, destitution and squalor (see Figure 3). This is a macro problem that we argue must be resolved in a micro way (see Table 1), primarily because under the present circumstances macro major political and economic interventions may not come forth in the near future.

Given this macro-micro (Quadrant Three) focus, we next argue that the BOP should be the primary focus of the global poverty eradication problem (GPEP) and its resolution programmes. Thus far, companies from high-income countries (e.g. U.S, Canada and Europe) have accessed the low-income countries (e.g. the poorest 30 countries of the world) in search of cheap labour and raw materials. One way this trend can be stopped as we argued before, is by enabling the lowincome countries to participate in the growth economies around world markets (e.g. coffee farmers in Africa being offered contracts on their production and training in growing quality beans by the U.S; based Starbucks Corporation). Another way involves offering the BOP market high-quality low-cost products and services that are the results of catalytic entrepreneurial interventions (e.g. Aravind Eye Care) which we discuss in the following section. 


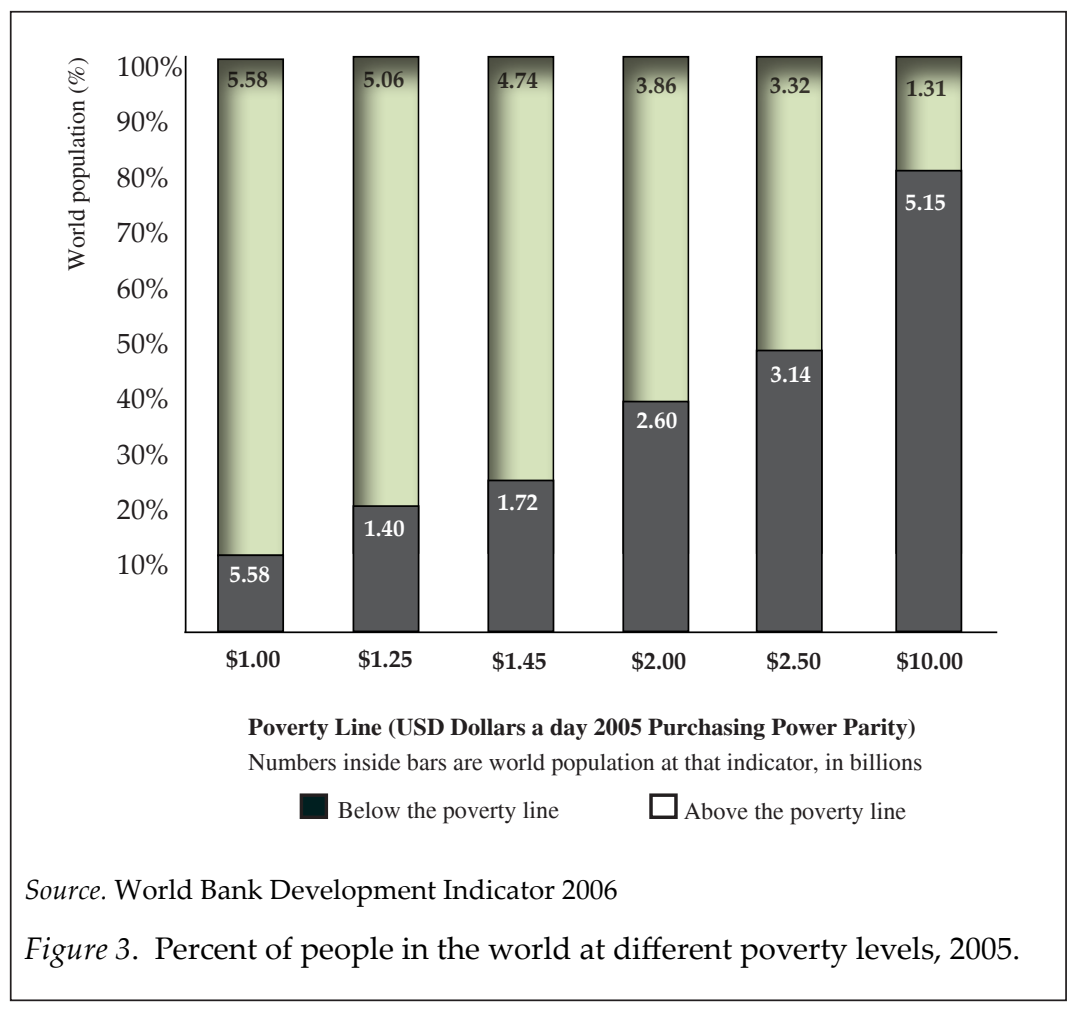

\section{Catalytic Entrepreneurial Innovations}

Innovation is bringing new ideas and concepts to the market place in the form of useful products and services. Innovation occurs where the rubber meets the road, where you obtain a market-ready solution to a problem (need, want or dream) that people experience. An innovation occurs when a creative idea becomes a design concept versus an abstract one. Innovation is the use of new technological and market knowledge to offer a new product or service that customers want (Afuah, 1998).

In his Innovator's Dilemma, Christensen (1997) proposed three types of innovations: sustaining innovations, low-end disruptive innovations and new-market disruptive innovations. Certain innovations disrupt the normal trajectory of life and organizations, and hence they are called disruptive innovations. Disruptive innovations introduce a new value proposition either by creating new markets or reshaping existing markets.(Christensen, 1997; 2009). 
Christensen, Heiner, Rudy, and Thomas (2006: 96-97) describe a sub-category of disruptive innovation, called catalytic innovations. Catalytic innovators share five qualities: (a) They create systemic social change through scaling and replication; (b) they meet a need that is underserved (because the existing solution is more complex than that many people require) or not served at all; (c) they offer products and services that are simpler, less costly than the existing alternatives, and may be perceived as having a lower level of performance, but to the less-demanding users that are meant to be good enough; (d) they generate resources, such as donations, grants, volunteer labour, or intellectual capital, in ways that are initially unattractive to incumbent competitors, and (e) they are often ignored, disparaged or even discouraged by existing players for whom the business model is unprofitable. Catalytic innovations are par excellence social innovations, and they take place under all structures, profit or non-profit, private or public, big or small. Examples of catalytic innovations abound (e.g. The Grameen Bank for Microfinance, Ashoka, \& Aravind Eye Care).

\section{Catalytic Innovations for the Bottom of the Pyramid}

Specifically, Hart and Christensen (2002), Prahalad and Hart (2002), Prahalad and Hammond (2002), and Prahalad (2011) propose a way that low-income countries can participate in the major markets and economies of the developed world. This is done through active interventions by multinationals to bring disruptive product innovations to the BOP markets first, before launching them in highincome markets. General Electric introduced a much less expensive ultrasound machine to the BOP markets much earlier using a BOP market as a testing base (Sheth, 2011). Such interventions helped the $\mathrm{BOP}$ indirectly to develop native capabilities and the infrastructure for improving the basic amenities of life (such as food, water, shelter, clothing, sanitation, healthcare and education), thus empowering the BOP to resolve the ever-worsening GPEP (Sheth, 2011; Sen, 2011).

Low-income countries have been largely neglected by the multinationals. The major barriers have been the economic, political and cultural distances between the TOP and the BOP markets. Currently, and presumably, because of the BOP theory pioneered by Prahalad and his colleagues (Hart, 2005; Hart \& Christensen, 2002; Prahalad, 2009; Prahalad, 2011; Prahalad \& Hammond, 2002; Prahalad \& Hart, 2002), certain corporations have been paying more attention to low- and middle-income countries as markets for products adapted to local needs and preferences (e.g. shampoo, aspirin, water). 
Our contention is that the economic, political and even cultural distances between high-income and low-income countries and their markets can be bridged by disruptve and catalytic innovations, launched especially by social entrepreneurs (Immelt, Govindarajan, \& Trimble, 2009).

Resistance to change almost always arises from threats to traditional ways of doing things or norms or status quo. Often these norms are woven into the fabric of established power relationships. That is, the norm is entrenched because the distribution of authority and control is entrenched. Eradicating global poverty requires doing "things" that pulls the TOP out of their comfort zones. Comfort zones are the emotional distance that the TOP has managed to create between them and the BOP. Discerning the source of resistance to change may be one of the keys to alleviating global poverty.

Table 2 proposes our theory of catalytic social entrepreneurial interventions between the (TOP) high income and emerging countries into the (BOP) low-income countries (and desperate poverty ghettos of the high-income countries-such as urban pockets within cities such as East Detroit). If we classify countries as high-income, middleincome emerging, and low-income countries trying to market their technologies and products to the BOP customers of the high-income, middle-income emerging, and low-income countries, then Table 2 captures the resulting $3 \times 3$ interventions or market transactions. Of these we single out those social entrepreneurial transactions (italicized in Table 2) as having much potential for alleviating and eventually eradicating global desperate poverty. That is, we contend that highquality low-cost products and services generated by disruptive, catalytic entrepreneurial innovations and interventions (Christensen, 2009), but adapted to local needs, preferences and buying power can transact between (Sheth, 2011):

1. High-income countries and the BOP households of developed countries (see Table 2, Cell 1).

2. High-income countries and the BOP households of emerging countries (Cell 2).

3. High-income countries and the BOP customers of low-income countries (Cell 3).

4. Middle-income countries and the BOP ghettos of developed countries (Cell 4).

5. Middle-income countries and the BOP households of emerging countries (Cell 5).

6. Middle-income countries and the BOP households of lowincome countries (Cell 6). 
7. Low-income countries and the BOP households of high-income countries (Cell 7).

8. Low-income countries and the BOP households of emerging countries (Cell 8).

9. Low-income countries and the BOP households of low-income countries (Cell 9).

Each of these nine interventions can alleviate and progressively eradicate global desperate poverty rampant in the BOP customer segments of these markets. Hart (2005) argues that such high-income country interventions can drive sustainable development at the BOP as long as they develop native capabilities and become indigenous to the local market. London and Hart (2004) prove that high-income country multinationals that collaborate with non-traditional partners such as local governments, non-profit organizations, and other groups of the BOP countries are more successful than collaborating with traditional partners such as large companies and the national governments of such countries. Prahalad and Hammond (2002) extend the list of the non-traditional partners to local entrepreneurs, business consortia, and women.

Table 2

Conditions for Marker Entry into the Bottom of the Pyramid Markets

\begin{tabular}{llll}
\hline $\begin{array}{c}\text { Companies } \\
\text { from: }\end{array}$ & Marketing Products to: \\
\hline $\begin{array}{l}\text { High- } \\
\text { income } \\
\text { Countries }\end{array}$ & $\begin{array}{l}\text { Bottom of } \\
\text { the Pyramid } \\
\text { Households of } \\
\text { High-income } \\
\text { Markets }\end{array}$ & $\begin{array}{l}\text { Bottom of the } \\
\text { Pyramid of } \\
\text { Emerging Country } \\
\text { Markets }\end{array}$ & $\begin{array}{l}\text { Bottom of the } \\
\text { Pyramid of Low- } \\
\text { income Markets }\end{array}$ \\
& $\begin{array}{l}\text { Cell 1: Market } \\
\text { entry is easy } \\
\text { with no or low } \\
\text { economic, political } \\
\text { and cultural } \\
\text { distances. }\end{array}$ & $\begin{array}{l}\text { Cell 2: Market } \\
\text { entry is difficult } \\
\text { with medium or } \\
\text { high economic, } \\
\text { political } \\
\text { and cultural } \\
\text { distances, but is } \\
\text { surmountable with } \\
\text { offshored back- } \\
\text { office jobs. }\end{array}$ & $\begin{array}{l}\text { Cell 3: Market } \\
\text { entry is difficult } \\
\text { or not profitable } \\
\text { owing to high } \\
\text { economic, } \\
\text { political and } \\
\text { cultural distances, } \\
\text { unless market } \\
\text { offerings are dated } \\
\text { technologies, } \\
\text { obsolete products } \\
\text { and services. }\end{array}$ \\
& & &
\end{tabular}

(continued) 
IJMS 20 (2), (29-70) (2013)

\begin{tabular}{|c|c|c|c|}
\hline \multirow{2}{*}{$\begin{array}{l}\text { Companies } \\
\text { from: }\end{array}$} & \multicolumn{3}{|c|}{ Marketing Products to: } \\
\hline & $\begin{array}{l}\text { The products } \\
\text { are usually high } \\
\text { quality-high } \\
\text { cost that results } \\
\text { from radical } \\
\text { or incremental } \\
\text { innovations, } \\
\text { technological } \\
\text { breakthroughs } \\
\text { and those offering } \\
\text { significant } \\
\text { differentiation. }\end{array}$ & $\begin{array}{l}\text { The products } \\
\text { are usually high } \\
\text { quality-high cost } \\
\text { that result from } \\
\text { radical innovations, } \\
\text { technological } \\
\text { or market } \\
\text { breakthroughs, } \\
\text { and those that } \\
\text { are affordable by } \\
\text { the large middle- } \\
\text { income segments } \\
\text { and the TOP. }\end{array}$ & $\begin{array}{l}\text { The products that } \\
\text { enter are also } \\
\text { high quality-high } \\
\text { cost that result } \\
\text { from radical } \\
\text { or incremental } \\
\text { innovations, } \\
\text { technological } \\
\text { or market } \\
\text { breakthroughs, but } \\
\text { are imported by or } \\
\text { for the TOP. }\end{array}$ \\
\hline & $\begin{array}{l}\text { High quality-low } \\
\text { cost (HQLC) } \\
\text { products resulting } \\
\text { from catalytic } \\
\text { entrepreneurship } \\
\text { that can help the less } \\
\text { demanding BOP } \\
\text { within the high- } \\
\text { income countries. }\end{array}$ & $\begin{array}{l}\text { HQLC products } \\
\text { that result from } \\
\text { catalytic social } \\
\text { entrepreneurship } \\
\text { that can help the less } \\
\text { demanding BOP } \\
\text { within the emerging } \\
\text { countries. }\end{array}$ & $\begin{array}{l}\text { HQLC products } \\
\text { that result from } \\
\text { catalytic social } \\
\text { entrepreneurship } \\
\text { can help the least } \\
\text { expecting people at } \\
\text { the BOP of the low- } \\
\text { income countries. }\end{array}$ \\
\hline \multirow[t]{2}{*}{$\begin{array}{l}\text { Middle- } \\
\text { income or } \\
\text { Emerging } \\
\text { Countries }\end{array}$} & $\begin{array}{l}\text { Cell 4: Market } \\
\text { entry is } \\
\text { challenging given } \\
\text { high and medium } \\
\text { economic, political } \\
\text { and cultural } \\
\text { distances with } \\
\text { respect to high- } \\
\text { income markets. }\end{array}$ & $\begin{array}{l}\text { Cell 5: Market } \\
\text { entry is relatively } \\
\text { easy with } \\
\text { equivalent } \\
\text { economic, } \\
\text { political and } \\
\text { cultural distances } \\
\text { among emerging } \\
\text { countries. }\end{array}$ & $\begin{array}{l}\text { Cell 6: Market } \\
\text { entry is difficult } \\
\text { but profitable } \\
\text { despite high } \\
\text { economic, political } \\
\text { and cultural } \\
\text { distances, } \\
\text { especially with } \\
\text { obsolete products, } \\
\text { technologies and } \\
\text { services. }\end{array}$ \\
\hline & $\begin{array}{l}\text { The products } \\
\text { are usually high } \\
\text { quality-high } \\
\text { cost that meet } \\
\text { global standards } \\
\text { or at least offer } \\
\text { significant } \\
\text { advantage or } \\
\text { differentiation. }\end{array}$ & $\begin{array}{l}\text { The products } \\
\text { are usually high } \\
\text { quality-medium } \\
\text { cost that result } \\
\text { from radical } \\
\text { or incremental } \\
\text { innovations, } \\
\text { technological } \\
\text { or market } \\
\text { breakthroughs that } \\
\text { offer competitive } \\
\text { price advantage } \\
\text { or significant } \\
\text { differentiation to } \\
\text { the customer base. }\end{array}$ & $\begin{array}{l}\text { Some products } \\
\text { that enter are } \\
\text { high quality-high } \\
\text { cost that result } \\
\text { from radical } \\
\text { or incremental } \\
\text { innovations, } \\
\text { technological } \\
\text { or market } \\
\text { breakthroughs, but } \\
\text { are imported by or } \\
\text { for the TOP. }\end{array}$ \\
\hline
\end{tabular}

(continued) 
IJMS 20 (2), (29-70) (2013)

\begin{tabular}{|c|c|c|c|}
\hline \multirow{2}{*}{$\begin{array}{l}\text { Companies } \\
\text { from: }\end{array}$} & \multicolumn{3}{|c|}{ Marketing Products to: } \\
\hline & $\begin{array}{l}\text { HQLC products } \\
\text { that result } \\
\text { from disruptive } \\
\text { innovations or } \\
\text { catalytic social } \\
\text { entrepreneurship } \\
\text { that can help the } \\
\text { less demanding } \\
\text { BOP ghetto markets } \\
\text { within the high- } \\
\text { income markets. }\end{array}$ & $\begin{array}{l}\text { HQLC products } \\
\text { that result } \\
\text { from disruptive } \\
\text { innovations } \\
\text { or catalytic } \\
\text { entrepreneurship } \\
\text { that can help the less } \\
\text { demanding BOP } \\
\text { in the emerging } \\
\text { countries. }\end{array}$ & $\begin{array}{l}\text { HQLC products } \\
\text { that result } \\
\text { from disruptive } \\
\text { innovations or } \\
\text { catalytic social } \\
\text { entrepreneurship } \\
\text { can help the least } \\
\text { expecting bottom of } \\
\text { the BOP within low- } \\
\text { income countries. }\end{array}$ \\
\hline \multirow[t]{2}{*}{$\begin{array}{c}\text { Low-income } \\
\text { Countries }\end{array}$} & $\begin{array}{l}\text { Cell 7: Market } \\
\text { entry is virtually } \\
\text { closed owing to } \\
\text { high economic, } \\
\text { political and } \\
\text { cultural distances. }\end{array}$ & $\begin{array}{l}\text { Cell 8: Market } \\
\text { entry is open } \\
\text { despite economic, } \\
\text { political and } \\
\text { cultural distances. }\end{array}$ & $\begin{array}{l}\text { Cell 9: Market } \\
\text { entry is relatively } \\
\text { easy within } \\
\text { equivalent } \\
\text { economic, political } \\
\text { and cultural } \\
\text { distances. }\end{array}$ \\
\hline & $\begin{array}{l}\text { HQLC products that } \\
\text { result from catalytic } \\
\text { entrepreneurship } \\
\text { can help the least } \\
\text { expecting BOP } \\
\text { of the low-income } \\
\text { countries. }\end{array}$ & $\begin{array}{l}\text { HQLC products } \\
\text { that result } \\
\text { from disruptive } \\
\text { innovations or } \\
\text { catalytic social } \\
\text { entrepreneurship } \\
\text { can help the least } \\
\text { expecting BOP of the } \\
\text { Low-income } \\
\text { countries. }\end{array}$ & $\begin{array}{l}\text { HQLC products } \\
\text { that result } \\
\text { from disruptive } \\
\text { innovations or } \\
\text { catalytic social } \\
\text { entrepreneurship } \\
\text { can help the least } \\
\text { expecting BOP of } \\
\text { the Low-income } \\
\text { countries. }\end{array}$ \\
\hline
\end{tabular}

\section{Striking Examples of Catalytic Social Entrepreneurship (CSE)}

As of date most of the striking examples of catalytic social entrepreneurship along all of the above nine possible interventions have come from individuals or non-profit institutions from various high-income, emerging and low-income countries. For instance:

- $\quad$ Cells 7, 8 and 9 (of Table 2): The Grameen Bank: Conventional banks are typically unwilling to lend to entrepreneurs or people without collateral, and the latter are forced to seek informal loans that could be exorbitantly expensive (with interest rates of 300 per cent to 3,000 per cent). Grameen Bank is a micro lending or micro financing organization that makes such loans possible with no collateral and with low interest 
rates. Muhammad Yunus, a professor of economics, a Nobel Laureate for Peace in 2006, believes that the poor have skills that remain under-utilized, mainly because existing institutions and policies fail to offer the support these people require. He founded the Grameen Bank in 1976 to supply credit to those who would not qualify at established commercial banks. At the end of 2005, Grameen operated more than 1250 branches, serving over 5.6 million borrowers in nearly 60,000 villages throughout Bangladesh. Since its inception in 1976, the bank has lent more than $\$ 5.2$ billion with a recovery rate of more than 98 per cent. The bank is owned 93 per cent. by its borrowers, 5 per cent by the Bangladeshi government, and 2 per cent by other private Bangladesh banks. The bank has been profitable almost every year since its inception. It differs from other lending institutions on three counts. First, priority is given to designing the system so that the loans can be repaid, and on time. Second, only the poorest villagers, the landless, are eligible. Third, the bank makes efforts to lend primarily to women, who are not only economically but also socially impoverished. The loan disbursal design is unique. To qualify for a loan, a villager must demonstrate that her family assets are below a certain threshold. She is not required to put up collateral; instead, she must join a five-member group and a forty-member center, and attend a weekly meeting. She must also share responsibility for the loans granted to the other members of her group; it is the group, not the bank, which initially evaluates loan requests. Defaulters would spoil things for everybody, so group members must choose their partners wisely. The Grameen Bank has been profitable from the outset, and has inspired a global micro-credit movement that has spread 65 developing countries, reaching 17 million borrowers by 2005 .

Cells 1, 2 and 3: Nfte-National Foundation For Teaching Entrepreneurship: Steve Mariotti, Founder And President Of The National Foundation For Teaching Entrepreneurship (Nfte) Is An Expert In Education For At-Risk Youths. For More Than 20 Years, He Has Been Helping Young People Develop Marketable Skills By Learning About Entrepreneurship. He Chose To Teach In Notorious Neighbourhoods Such As Bedford-Stuyvesant In Brooklyn And The "Fort Apache" Section Of The South Bronx. It Was At Jane Adams Vocational High School In The Bronx That He Developed The Insight And Inspiration To Bring Entrepreneurial Education To Low-Income Youths. This Led To Founding The Nfte In 1987. Its Mission Is To Teach 
Entrepreneurship To Low-Income Young People So They Can Become Economically Productive Members Of Society By Improving Their Academic, Business, Technology And Life Skills. Nfte Is A 501(C) (3) Nonprofit Organization And Has Currently A 22-Year Track Record As A Proven Programme Model In Areas Of Business Knowledge And Business Formation. The Organization Reached Over 22,000 Young People In 2005 And Has Trained Teachers And Youth Workers In 44 States And 16 Countries.

- Cells 5 and 6: Low cost eye glasses.com: Over one billion people need eyeglasses but do not own them. They have correctable vision problems but are often handicapped due to lack of finance. Eyeglasses could correct the majority of vision problems encountered in the developing world, reducing the impact of presbyopia, myopia, hyperopia, and astigmatism. Without eyeglasses, simple tasks become more difficult or impossible, productivity slows, and accidents occur more frequently. Based purely on the lack of productivity and enjoyment, the lack of eyeglasses is one of the largest solvable problems in the developing world. In fact, it is significantly more common than problems such as cataracts or glaucoma. The surprisingly low penetration of eyeglasses on a global basis is a result of the fundamental structure of the eye care industry. The current commercial eye-care system is designed for the wealthy, first world customer, and espouses its customers' values. The system is characterized by extreme product diversity, customized product combinations, highlytrained specialists, and a fashion focused product design and buying processes. As a result, prescription glasses are unaffordable by the majority of people in the world, and access is severely limited. In most developing nations, there are few optometrists, and those that are present live primarily in major cities. Any solution must be: available, low cost, scalable, and wearable. To be available, glasses should be easily purchased from a convenient local location. To be low cost, they should cost a few days' wages. In most situations, prices starting at \$5 are low cost. Cheap Eye Glasses project does exactly this.

- $\quad$ Cells 1, 2 and 3: Ashoka: Innovators for the Public. Based in Arlington, VA, Bill Drayton launched Ashoka in 1980 with $\$ 50,000$. By 2005, Ashoka's budget rose to $\$ 30.5$ million and funded 1,600 "fellows" or social entrepreneurs in 60 countries. 
Mohammad Yunus was an Ashoka fellow. Drayton named his organization after emperor Ashoka (c. 300 BC), a great Indian visionary who waged war to unite South Asia. He subsequently renounced violence, adopted Buddhism, and dedicated his empire to tolerance, economic growth, and social projects. Through his global nonprofit Ashoka, Drayton visions to change the world by systematically identifying change-makers around the world to provide them with support and modest "social venture capital," and watch as they transform ingrained institutions and improve lives exponentially. It is a model of change that Drayton calls social entrepreneurship - a term he coined to describe individuals who combine the pragmatic and results-oriented methods of a business entrepreneur with the goals of a social reformer. Bill Drayton witnessed the power of a simple idea to effect vast social change. Fellows, who must undergo a rigorous testing and screening process and numerous interviews, have done things like finding a way to provide cheap electricity for Brazilian farmers, changing the Indian school curriculum from rote to independent learning, and distributing micro-credit loans of as small as $\$ 60$ for poor women in Bangladesh to start businesses. Ashoka has set a new standard in development work and microfinance is now used all over the world to help add to the ranks of the world's entrepreneurs. Within five years, says Drayton, more than 50 per cent of Ashoka fellows worked to change the national policies in their respective countries. Drayton saw that while government can be inefficient and the private sector motivated by profit, the nonprofit sector was ripe to provide change. Indeed, this "third" sector, or the citizen sector, as Drayton calls it, has exploded - 70 per cent of registered nonprofit groups in the United States are under 30 years old. "More and more people want to do this kind of work," says Drayton. "We are creating the jobs; the salaries are going up. We are desperate for managers." Much of the change in the citizen sector can be attributed to Drayton, who made it his life's work to not only expand Ashoka but also develop the field as a whole.

- Cells 1, 2 and 3: A World of Good: A growing group of practitioners, investors and philanthropists are advancing strategies that intentionally blend social, environmental and economic value. These activities have resulted in an exciting wave of new practices across the for-profit and nonprofit sectors. One such practitioner, Priya Haji, initiated her second 
socially conscious endeavor in ten years. As a senior at Stanford University, Priya partnered with David Lewis in 1994 and together, with the help of the Echoing Green Fellowship, has opened Free At Last, a community-based drug treatment and prevention programme in East Palo Alto, CA. The organization that began with two people, had a staff of 60 serving over 3,000 people annually, by the time she left to pursue her MBA. With fellow Haas Business School graduate SiddharthSanghvi, Priya launched World of Good, a socially responsible venture that markets and sells handicrafts from artisans and cooperatives all over the world to the US mainstream market. The model borrows across sectors to fulfill a simple goal: to catapult fair trade products from a niche into the mainstream market. Priya desegregates economic, social and environmental principles in the strategies she fuses into World of Good hoping to create a profitable, meaningful vehicle for social change. Fair trade is based on several conditions to ensure sustainable incomes for producers in developing countries: (1) paying a fair price for their goods so that they can cover the cost of production and earn a living wage; (2) maintaining stable, long-term trade agreements that provide consistent sales and security; and for some, (3) supporting the fair trade movement through working-condition reform and consumer education.

- Cells 4, 5 and 6: SKS Microfinance, Nizamabad, India: VikramAkula, a Yale graduate in International Relations, founded SKS Microfinance in 1998 to build the "next generation microfinance company" (Akula, 2011). SKSM is patterned partially on the microfinance strategy of the Grameen Bank founded by Muhammad Yunus in 1976. While most microfinance institutions modelled on the Grameen Bank are small nonprofits, 80 per cent of which serve less than 10,000 customers (roughly serving about 140 million in total), there are another 4 billion people in the world earning less than $\$ 2$ a day (i.e. about 750 million households) that need microfinance coverage. In other words, non-profit microfinance institutions are not scalable operating systems that can reach larger needy populations. This is primarily because non-profit microfinance schemes lack access to commercial banks, as the cost of handling millions of micro transactions could be costprohibitive. The SKSM business strategy, accordingly, is based on entrepreneurial principles based on fast-scaling consumer businesses like McDonald's and Starbucks. 
- Cells 1, 2 and 3: Online Schools: For-profit Apex Learning and non-profit Virtual High School and Florida Virtual School, among others, provide specialized classes (e.g. certain language courses, advanced placement courses that count for college credit) online to thousands of students from public schools in poorer areas that do not or cannot afford to offer these courses. Online learning curricula offer such courses at a fraction of what landline courses would cost. According to the U.S Department of Education, 200,000 students attend online schools full-time, often charter schools that appeal to home-schooling families. However, students enrolled in online courses experience online learning as technically challenging and which require much higher levels of self-disciple and self-motivation than regular schools. Future catalytic innovations should try to make online education user-friendly and attractively self-motivating. Given the global reach of the internet technology, quality online schools can be scaled to serve the BOP markets.

Cell 1: Community Colleges: These have dramatically changed the shape of higher education in the U. S. by expanding access to and redefining the goals of higher learning. Community colleges offer a lower-cost alternative to four-year over-priced universities, are more easily and locally accessible and report higher placement rates. Community Colleges now enroll around 44 per cent of all undergraduates in the United States. Most students pursue community college education for the first two years and then move to universities that allow the transfer arrangements.

Cell 1: Minute-Clinic, MN: Minneapolis-based Minute-Clinic has 87 for-profit clinics located in ten states in CVS stores and other retail locations and provides fast, affordable walk-in diagnosis and treatment for common health problems, as well as vaccinations. Minute-Clinic employs quality nurse practitioners armed with software based protocols and applies strict rules of quality care. Patients that have complaints or problems outside the range of Minute-Clinic (MC) issues are referred to doctors or to a nearby emergency room. Underserved, uninsured and underinsured patients find Minute-Clinic very convenient, adequate and affordable. Recent surveys of MC reveal that more than 350,000 patients indicate 99 per cent satisfaction. $\mathrm{MC}$ was recently acquired by CVS because of its growth and profit possibilities. Other similar healthcare systems are RediClinics, Take Care Health Systems, and Wal-Mart's in- 
store health clinics. Similarly, Detroit Medical Centre (DMC) extends its quality and comprehensive care to the inner-city poor by training its nurses to offer care that doctors formerly had provided, but at a lower cost.

- Cell 1: Freelancers Union, NY: FU is a non-profit labour organization providing low-cost health insurance and other services to independently employed contractors, consultants, pro-temps, and other insurers in the New York area who could not otherwise afford insurance. FU offers comprehensive health group insurance at prices that are 30 per cent to 40 per cent lower than competing large insurance companies that often cater to large corporate clients, and would not serve the poor segments. FU discovered this "blue ocean," has enlarged its services and numbers to other parts of the state. The catalytic innovation model where FU acts as a marketer and broker while partnering with an established insurance carrier, is replicable, and FU is now expanding to other states.

\section{Discussion}

The problem of poverty is the gap between what "we can do" (i.e. knowledge and technology) and "what we should do" (ethics and moral imperatives). Technology and technological progress can be one-sided neglecting the poor. We need ethical discernment to ask at every stage of a technological breakthrough - why do we need this? How will it humanize us rather than commoditize and monetize us? How will it positively impact the BOP? The field of ethics should question the human significance of any undertaking that has an impact upon the individual and society. With every technological advance the hungry nations of the world (BOP) cry out even louder to the people blessed with abundance (TOP).

What is humanizing and what is dehumanizing are the two ethical criteria that must be applied to any activity. Any activity that perpetuates poverty is dehumanizing. Any activity that assaults human dignity and solidarity is dehumanizing. We have to assess great technologies and subsequent activities and movements of today such as globalization, digitization, automation, bioengineering, telecommunication, animation, global networking and the social media from this humanization-dehumanization lens. We must test catalytic social entrepreneurship (CSE) solutions with endemic global 
poverty with the same lens -will they humanize the people alleviated from global poverty or dehumanize them?

To the extent that such CSE solutions adequately respond to the basic needs of the BOP, they humanize the BOP. Table 3 prescribes a specific humanization check on every CSE solution one plans to adopt. Table 3 considers various layers of desperate poverty, their possible symptoms, possible causes, and it suggests possible catalytic entrepreneurial interventions for developing native ability in relation to the basic unanswered need.

For instance, lack of basic healthcare (layer of need) spawns and rapidly diffuses epidemic diseases (symptoms) which are, in turn, caused by several root causes such as contaminated water, rivers, lakes, land and air, lack of clean drinking water, lack of water for daily cooking and sanitation needs, lack of first-aid and clinical facilities, lack of nurses and paramedics, and lack of doctors and hospitals, and in general, lack of disease prevention systems. Table 3 suggests CSE solutions that address the root causes of each of the lack of the healthcare symptoms. Other entries in Table 3 are similarly explained. Obviously, Table 3 is a sample representation of the problem of global desperate poverty.

Education is a key determinant of economic well-being for individuals, groups, cities and villages. Despite massive diffusion of educational institutions in some nations such as India, the "rural" population have little access to quality education. Hence, providing a quality education for all, especially in rural areas where the majority lives, is a great strategy for alleviating poverty.

\section{Poverty Eradication as a Business Opportunity}

Every single social and global issue of our day, said Peter Drucker, can be a business opportunity in disguise. Global poverty is a serious social and global issue today and can be a serious business opportunity. Aid, subsidies, grants and philanthropy are not the long-term solutions to massive global poverty. The real opportunity is local development of the private sector in the BOP markets (Prahalad, 2009). This paper explores this opportunity.

Business opportunities abound at the bottom of the economic pyramid (Hammond \& Prahalad, 2004). Successful examples of capitalizing this opportunity are documented. For instance, Muhammad Yunus founded the micro financing Grameen Bank 
with the idea that small loans to poor people could fund larger businesses while lifting the poor from their poverty. Going beyond microlending, Yunus proposed a social business model that can coexist and support even traditional for-profit businesses. His win-win model currently helps over 8 million borrowers and has eradicated poverty significantly in several developing countries that have adopted this model.

Using a variation of Yunus' model, John Hatch founded the Foundation for International Community Assistance (FINCA) to address the micro financing needs of the poor. The village banks that FINCA founded provide start-up funding for village entrepreneurs such that the entire village may bootstrap its way out of poverty to economic viability. Today, FINCA assists more than 10 million in the BOP markets around the world.

In theory, C. K. Prahalad (2009) has argued that the best win-win possibility of lifting the poor out of vicious poverty cycles is to engage them in for-profit businesses providing goods and services (e.g. bakeries, healthcare, communication and home-building services) in economically disadvantaged countries and communities. He argued that businesses can profit from the BOP markets while alleviating global poverty. Given that the basic survival needs of the poor are taken care of (as partially indicated in Table 3), the next stage is to engage the BOP in for-profit businesses providing goods and services that serve basic wants.

\section{Globalization and Endemic Global Poverty}

Globalization, as described by the Copenhagen Declaration, is a consequence of increased human mobility, enhanced communications, greatly increased trade and capital flows, and technological developments. The Copenhagen Declaration affirms that globalization opens new opportunities for sustained economic growth and the development of a global economy, particularly for the developing countries. By its very nature, globalization should drive toward being one world, interdependent upon one another, and empower us to discern more clearly that we are one human family.

Nevertheless, globalization has another face. Its rapid processes of change and adjustment have been accompanied by increases in poverty, unemployment, social disintegration and exclusion. For instance, crime has globalized, especially in its concrete manifestations of drug traffic and terrorism (Rodriguez, 2006). 
IJMS 20 (2), (29-70) (2013)

Table 3

Layers of Desperate Poverty and Exigent Catalytic Entrepreneurial Interventions

\begin{tabular}{|c|c|c|c|}
\hline $\begin{array}{l}\text { Layers of } \\
\text { desperate } \\
\text { poverty }\end{array}$ & $\begin{array}{l}\text { Possible } \\
\text { symptoms }\end{array}$ & Possible causes & $\begin{array}{l}\text { Possible catalytic } \\
\text { entrepreneurial Interventions } \\
\text { for developing native ability } \\
\text { in relation to: }\end{array}$ \\
\hline \multirow{12}{*}{$\begin{array}{l}\text { Less than } \\
\text { adequate } \\
\text { healthcare }\end{array}$} & \multirow[t]{6}{*}{$\begin{array}{l}\text { Epidemic } \\
\text { disease } \\
\text { proneness \& } \\
\text { diffusion }\end{array}$} & $\begin{array}{l}\text { Contaminated } \\
\text { water, rivers, } \\
\text { lakes, land } \\
\text { and air }\end{array}$ & $\begin{array}{l}\text { High quality affordable (HQA) } \\
\text { industrial pollution stoppers or } \\
\text { de-pollution devices for each } \\
\text { community }\end{array}$ \\
\hline & & $\begin{array}{l}\text { Lack of clean } \\
\text { drinking water }\end{array}$ & $\begin{array}{l}\text { HQA water bottles, rain } \\
\text { water harvesters, storage and } \\
\text { purifiers }\end{array}$ \\
\hline & & $\begin{array}{l}\text { Lack of water for } \\
\text { daily cooking and } \\
\text { sanitation needs }\end{array}$ & $\begin{array}{l}\text { HQA bore wells and water } \\
\text { purifiers for each village } \\
\text { community }\end{array}$ \\
\hline & & $\begin{array}{l}\text { Lack of first- } \\
\text { aid and clinical } \\
\text { facilities; lack } \\
\text { of nurses and } \\
\text { paramedics }\end{array}$ & $\begin{array}{l}\text { HQA first-aid kits for home use; } \\
\text { mobile health clinics with } \\
\text { nurses and paramedics }\end{array}$ \\
\hline & & $\begin{array}{l}\text { Lack of doctors } \\
\text { and hospitals }\end{array}$ & $\begin{array}{l}\text { HQA ambulatory care with a } \\
\text { family practitioner and nurse }\end{array}$ \\
\hline & & $\begin{array}{l}\text { Lack of disease } \\
\text { prevention } \\
\text { systems }\end{array}$ & $\begin{array}{l}\text { HQA disease prevention } \\
\text { vaccines and injections or } \\
\text { antibiotics }\end{array}$ \\
\hline & \multirow[t]{6}{*}{$\begin{array}{l}\text { High } \\
\text { infantile } \\
\text { mortality; }\end{array}$} & $\begin{array}{l}\text { Lack of neonatal } \\
\text { care and post- } \\
\text { natal care; }\end{array}$ & $\begin{array}{l}\text { HQA (HQA) neo/post natal } \\
\text { care units for pregnant and } \\
\text { nursing mothers at home and/ } \\
\text { or village clinics }\end{array}$ \\
\hline & & $\begin{array}{l}\text { Undernutritioned } \\
\text { pregnancy and } \\
\text { thereafter; }\end{array}$ & $\begin{array}{l}\text { HQA high-nutrition meals for } \\
\text { pregnant and nursing mothers }\end{array}$ \\
\hline & & $\begin{array}{l}\text { Lack of maternity } \\
\text { hygiene and } \\
\text { sanitation }\end{array}$ & $\begin{array}{l}\text { HQA hygiene-sanitation } \\
\text { products or services for } \\
\text { pregnant and nursing mothers; }\end{array}$ \\
\hline & & $\begin{array}{l}\text { Lack of } \\
\text { gynecological care }\end{array}$ & $\begin{array}{l}\text { HQA ambulatory baby- } \\
\text { delivery care }\end{array}$ \\
\hline & & $\begin{array}{l}\text { Lack of mother's } \\
\text { milk }\end{array}$ & $\begin{array}{l}\text { HQA mother-milk stimulants } \\
\text { or substitutes }\end{array}$ \\
\hline & & $\begin{array}{l}\text { Lack of early } \\
\text { infancy or toddler } \\
\text { care }\end{array}$ & HQA infant care services \\
\hline
\end{tabular}

(continued) 
IJMS 20 (2), (29-70) (2013)

\begin{tabular}{|c|c|c|c|}
\hline $\begin{array}{l}\text { Layers of } \\
\text { desperate } \\
\text { poverty }\end{array}$ & $\begin{array}{l}\text { Possible } \\
\text { symptoms }\end{array}$ & Possible causes & $\begin{array}{l}\text { Possible catalytic } \\
\text { entrepreneurial Interventions } \\
\text { for developing native ability } \\
\text { in relation to: }\end{array}$ \\
\hline \multirow{15}{*}{$\begin{array}{l}\text { Less than } \\
\text { adequate } \\
\text { educational } \\
\text { facilities }\end{array}$} & \multirow{10}{*}{$\begin{array}{l}\text { Lack of early } \\
\text { educational } \\
\text { care }\end{array}$} & $\begin{array}{l}\text { Lack of } \\
\text { kindergartens }\end{array}$ & HQA kindergartens \\
\hline & & $\begin{array}{l}\text { Ineffective } \\
\text { kindergarten } \\
\text { teachers }\end{array}$ & HQA kindergarten teachers \\
\hline & & $\begin{array}{l}\text { Lack of middle } \\
\text { schools }\end{array}$ & HQA middle schools \\
\hline & & $\begin{array}{l}\text { Lack of middle } \\
\text { school teachers }\end{array}$ & HQA middle school teachers \\
\hline & & $\begin{array}{l}\text { Lack of school } \\
\text { lunch programmes }\end{array}$ & HQA school lunch programs \\
\hline & & $\begin{array}{l}\text { Lack of } \\
\text { recreational } \\
\text { amenities }\end{array}$ & HQA recreational amenities \\
\hline & & $\begin{array}{l}\text { Lack of adolescent } \\
\text { skills }\end{array}$ & HQA adolescent skills training \\
\hline & & $\begin{array}{l}\text { Lack of youth food } \\
\text { care }\end{array}$ & HQA youth nutritional care \\
\hline & & Lack of libraries & $\begin{array}{l}\text { HQA adolescent modern } \\
\text { libraries }\end{array}$ \\
\hline & & $\begin{array}{l}\text { Lack of online } \\
\text { resources }\end{array}$ & $\begin{array}{l}\text { HQA youth networking } \\
\text { resources }\end{array}$ \\
\hline & \multirow{5}{*}{$\begin{array}{l}\text { Lack of } \\
\text { adolescent } \\
\text { technical } \\
\text { schools }\end{array}$} & $\begin{array}{l}\text { Lack of adolescent } \\
\text { mentoring }\end{array}$ & $\begin{array}{l}\text { HQA adolescent mentors/ } \\
\text { coaches }\end{array}$ \\
\hline & & $\begin{array}{l}\text { Lack of youth } \\
\text { value care }\end{array}$ & $\begin{array}{l}\text { HQA youth value education } \\
\text { centers }\end{array}$ \\
\hline & & $\begin{array}{l}\text { Lack of youth } \\
\text { creativity } \\
\text { opportunities }\end{array}$ & $\begin{array}{l}\text { HQA youth creativity/ } \\
\text { innovation/ imagination/ } \\
\text { productivity centers }\end{array}$ \\
\hline & & $\begin{array}{l}\text { Lack of teenage } \\
\text { job skills }\end{array}$ & $\begin{array}{l}\text { HQA teenage-skills drilling } \\
\text { centers }\end{array}$ \\
\hline & & $\begin{array}{l}\text { Lack of teenage } \\
\text { entrepreneurship }\end{array}$ & $\begin{array}{l}\text { HQA teenage } \\
\text { entrepreneurship \& venture- } \\
\text { training centers }\end{array}$ \\
\hline
\end{tabular}

Globalization is simultaneously an opportunity and a risk. If well oriented to universal human values, globalization can be great opportunity for promoting economic progress, better equality, and better harmony, peace and solidarity. It is a risk, if globalization is not necessarily guided by human principles and universal values of 
equality and solidarity, human dignity and social justice. It is often guided by financial and oil interests, cheap labour markets and mineral resources, and frequently, by pure and simple greed. Globalization can deepen even further the difference in the quality of life between regions, countries and peoples, and within each, between the rich and the poor. This is what Figure 2 forecasts, unless joint responsibility is assumed by groups that represent and serve both the TOP (e.g. multinational corporations) and the $\mathrm{BOP}$ (e.g. national governments) to radically reverse the trends that Figure 2 envisages.

"Globalization has created new inequalities between those who enjoy the power given to them by knowledge, and those who are excluded from its benefits because they have no access to that knowledge" (Nicolas, 2010).

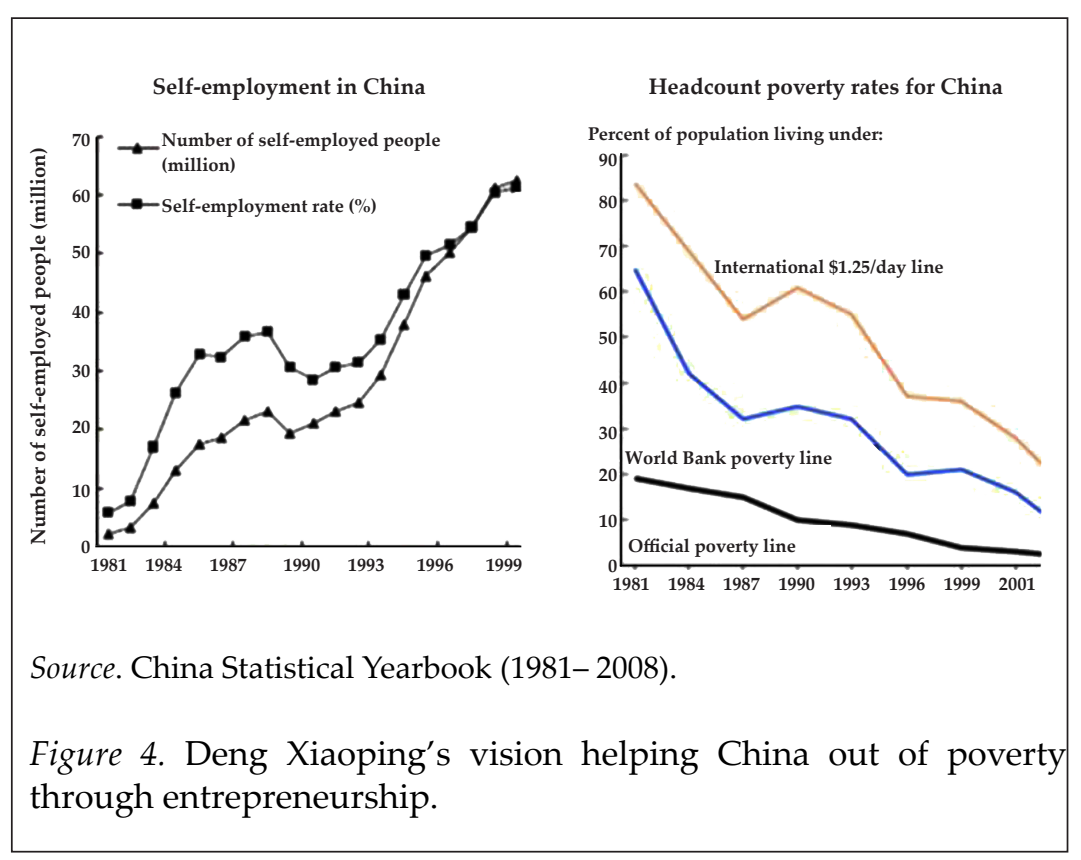

\section{Case Studies of Micro- and Macro-Catalysts to Alleviate Poverty}

Table 4 includes four case studies with two cases demonstrating micro-catalysts and two presenting macro-catalysts that helped reduce poverty. This table verifies the proposition stated at the end of the abstract. Since the paper focuses mainly on the micro- 
catalyst, in this section we focus on the two macro-catalysts. Mao Zedong tried the approach of redistributing wealth to achieve poverty reduction while Deng came up with the visionary idea of privatizing many public sectors while making sure the poor were not compromised in the process. From Table 5 it is evident that Deng is a miracle worker (as compared to Mao) and Figure 4 indicates that Deng's approach increases entrepreneurship while decreasing China's poverty level by a significant amount.

Table 4

Catalysts Creating Entrepreneurship Opportunities for the Poor

\begin{tabular}{|c|c|c|}
\hline Catalysts & What did they do? & Outcomes \\
\hline \multicolumn{3}{|c|}{ Micro-Catalysts } \\
\hline $\begin{array}{l}\text { Grameen Bank } \\
\text { (Founded by } \\
\text { M. Yunus) } \\
\text { http://www. } \\
\text { grameen-info. } \\
\text { org/ }\end{array}$ & Microfinance Tainting & $\begin{array}{l}\text { Income } \\
\text { Consumption } \\
\text { Education } \\
\text { Accommodation } \\
\text { Health } \\
\text { Women's empowerment }\end{array}$ \\
\hline $\begin{array}{l}\text { NFTE } \\
\text { (Founded by S. } \\
\text { Mariotti) http:// } \\
\text { www.nfte.com/ }\end{array}$ & $\begin{array}{l}\text { Class programme } \\
\text { Teaches student } \\
\text { Entrepreneur skills } \\
\text { Find students and } \\
\text { opportunity and } \\
\text { Start-up fund }\end{array}$ & $\begin{array}{l}\text { Increased interest in } \\
\text { attending college } \\
\text { Greater occupational } \\
\text { aspirations Improved } \\
\text { scores in independent } \\
\text { reading } \\
\text { Saved more than } 450,000 \\
\text { students }\end{array}$ \\
\hline $\begin{array}{l}\text { Deng Xiaoping } \\
\text { (former Chinese } \\
\text { President) } \\
\text { (See Figure 4) }\end{array}$ & $\begin{array}{l}\text { Open China's market } \\
\text { Invite FDI Downsized } \\
\text { state-owned enterprise }\end{array}$ & $\begin{array}{l}\text { Hundreds of millions of } \\
\text { people went out of poverty } \\
\text { Vibrant entrepreneurship } \\
\text { environment Staggering } \\
\text { number of entrepreneurs }\end{array}$ \\
\hline $\begin{array}{l}\text { BRAC } \\
\text { (Founded by } \\
\text { FazleHasan } \\
\text { Abed) } \\
\text { http://www. } \\
\text { brac.net/ }\end{array}$ & $\begin{array}{l}\text { Microfinance } \\
\text { Education } \\
\text { Healthcare } \\
\text { Legal services } \\
\text { Community } \\
\text { empowerment }\end{array}$ & $\begin{array}{l}\text { Increased self-reliance } \\
\text { Improved healthcare } \\
\text { Better education } \\
\text { Touched lives of } 126 \text { million } \\
\text { people in } 11 \text { countries }\end{array}$ \\
\hline
\end{tabular}


IJMS 20 (2), (29-70) (2013)

Table 5

Chinese Poverty Reduction Through a Macro-Catalyst (Deng)

\begin{tabular}{cccc}
\hline \multicolumn{4}{c}{$\begin{array}{c}\text { China's Economic Progress Under Two Different Philosophies } \\
(1950-1980 \text { mainly ruled by Mao, 1980-2010 by Deng's idea) }\end{array}$} \\
\hline Year & GDP (in billions) & Population (in millions) & GDP per capita \\
\hline 1950 & $\$ 67$ & 563 & $\$ 119$ \\
1980 & $\$ 189$ & 981 & $\$ 192$ \\
2010 & $\$ 7,300$ & 1340 & $\$ 5,447$ \\
\hline
\end{tabular}

Source. Universal Moral Values and Global Poverty Eradication.

Some fundamental moral universals should ground the poverty eradication effort in order to make the latter project desirable, feasible, viable and doable (Sachs, 2008). Some of these universals are: fundamental human rights to life, human dignity and the pursuit of happiness; human gender equality (men and women are equal) and equal opportunity such that woman-harassment, slavery and child labour are unacceptable; universal justice such that the innocent do not suffer, the guilty are not acquitted, and political suppression and economic oppression are unacceptable; and that the pursuit of health and happiness will at least include clean drinking water and basic sanitation for all; reasonable family privacy, HIV prevention, and the progressive reduction of maternal and infant mortality. All these moral universals are also social and global issues that can be, as per Drucker, disguised business opportunities that businesses must explore.

Reduction of economic inequality should be at least a second-order moral universal. Economic inequality within a society is associated with decreased well-being and increased poverty (Babones, 2008; Subramniam \& Karachi, 2003; Wilkinson \& Picket, 2006). A required moral change of attitude for poverty eradication is the progressive eradication of an old culture that believes that wealth is a sign of God's favor and, equivalently, that poverty is a sign of God's disfavour (Herberg, 1996). In general any economic inequality that destabilizes equality of opportunity (a first-order moral universal) should be unacceptable for the poverty eradication project. Equally strong second-order moral imperatives are entrepreneurship programmes that improve health, education and entrepreneurship among the poorest of the poor (Prahalad, 2009). 


\section{Areas for Future Research}

The causal links between corresponding pairs (A:a; B:b; ...H:h) are partly studied (Bales, 2004; Casal, 2004; Cohen, 2004; Collier, 2008; Naim, 2007; Okin, 1991; O'Neill, 1986; Sachs, 2006; Sobhan, 2005), and can serve as critical hypotheses for further research on poverty determinants. Similarly, the causal links between sequential phenomena (A-B; B-C; ...G-H, H-A; a-b, b-c; ... g-h, and h-a) are also partially researched, [Collier, 2008; Sachs, 2006; Sobhan, 2005; Yunus, 2007], but leaving several circular links as fruitful avenues for future global poverty research. If these causal links can be progressively established, city by city, village by village, state by state, country by country, continent by continent, then we can accordingly establish the causal network of global abject property. Eradication of global poverty would then be a world-wide project of instituting effective corrective procedures that would neutralize or eliminate these imbalances along both the circles describing the self-perpetuating domain of the TOP and the self-perpetuating dungeon of the BOP.

In systems-thinking, we must research the feedback loops, both reinforcing and balancing, that in the short run and long run contribute to chronic poverty. Much of the art of system dynamics is discovering and representing the feedback processes that, along with stock and flow structures, time delays and nonlinearities, determine the dynamics of the system (Sterman, 2010). Then, eradicating global desperate poverty becomes a project of preventive, protective, procedural and corrective justice.

Twentieth century business lacked good design, and hence, beauty and aesthetics. It overvalued short-term goals and profits and undervalued long-term broad aesthetics and humanity. Sumantra Goshal, a global business leader and author, argued that corporate business is "undersocialized and one-dimensional," and hence, it has only led to resentful customers, disgruntled and dispirited employees and a divided society. We need a much larger focus than the bottom line. A selfish focus on the bottom line of profits is a bad design. Good design, in contrast, is a new management model that deliberately includes a moral dimension. Future research into poverty eradication systems should include designful and moral systems into their strategies. A good design is a new management model that is a designful business that deliberately includes a moral dimension (Neumeier, 2008). It is a model that not only seeks the good of the shareholders, 
but the good of all other stakeholders as well such as customers, employees, suppliers, creditors, distributors, governments, and local communities. In short, its design is depth. A deep design business model does not work on an "either-or" philosophy of shareholders or stakeholders, but on the more challenging "and" philosophical view of including all stakeholders as well as the BOP.

\section{Conclusion}

Technology is powerful only if it is accessible. Broader access brings education, information, and a sense of community that can help combat AIDS, malnutrition, ignorance and neglect. The power of a connected and enlightened world community is just beginning. In bridging the digital divide that separated the networked from those who were not in the world, AMD initiated the $50 \times 15$ project of covering 50 per cent of humankind of the world by 2015 with communication and information technologies such as the Internet. Many Learning Labs from the 50x15 initiative are already present in Brazil, China, the Caribbean, and in Africa (Egypt, Ghana, Kenya, Lesotho, Mali, Mauritius, Rwanda, South Africa, Uganda) and many more are in the planning stage (ICT, 2010).

Although NGOs worked tirelessly to promote local solutions and local entrepreneurship, the idea of large-scale social entrepreneurship as a possible solution to global poverty has not yet taken root. In the past four millennia, kings, lords, politicians and bureaucrats, and managers in large domestic and global corporations have wrongly assumed that the poor are wards of the state (Prahalad, 2006). This flawed paternalistic mindset has kept the rich richer, with increasing power, while the poor have grown in numbers and in poverty and destitution. Currently, of the 7 billion population it has been estimated that about 1 billion earn less than $\$ 1$ a day (starvation level) and another 2 billion earn less than $\$ 2$ a day (desperate poverty). This is morally unconscionable.

Global social entrepreneurship requires governments, corporations, NGOs and the poor to co-create effective solutions to the problems of the BOP market. It mobilizes the commitment, investment and talent capacities of all stakeholder communities of the world, including the BOP, for engagement in the process of transforming the world. Such social entrepreneurship, obviously, goes beyond philanthropy and the pristine notions of corporate social responsibility. Transforming 
the BOP and thus, eradicating global poverty, illiteracy and disease, should be a mission fully integrated with the core activities of the governments, firms and the NGOs. "For sustaining energy, resources, and innovation, the BOP must become a key element of the central mission for large private sector firms. The poor must become active, informed, and involved consumers. Poverty reduction can result from co-creating a market around the needs of the poor" (Prahalad, 2011).

Having said that, two points must be made:

1. The TOP does not have to be lessened in any way by the BOP moving upward for example Bill Gates and Warren Buffet have collectively decided that the best usage of their extra ordinary wealth and expertise is to invest in the children and the poor of the world. They also, issued a challenge to other TOP members to join them. AzimPremji, an Indian Entrepreneur who started Wipro (a leading IT firm), has already accepted this challenge by donating almost to 2 billion dollars to the cause of the BOP (Bishop, 2008).

2. The rising up of the BOP is not automatic and will not happen tomorrow. It will take the best available technology, aggressive social entrepreneurship, plenty of patience, and great deal of time. Rome was not built in a single day and the BOP will not have its fortune reversed overnight.

From our earlier discussions it can be concluded that the domain, nature, content and direction of social innovations involve a very wide context - the human planet with its ecological and geographic legacies, the entire population of this earth, especially, the BOP and something to do with raising the standards of the quality of life for all people. In conclusion, the world urgently needs many more catalysts, both macro-and micro (as indicated in Table 4), that provide opportunities for the poor worldwide to enrich their lives.

\section{References}

Ackoff, R. L. (1974). Redesigning the future. New York: John Wiley and Sons.

Ackoff, R. L., \& Emery, F. E. (1972). On purposeful systems. Chicago, IL: Aldine Atherton.

Afuah, A. N. (1998). Innovation management. Oxford: Oxford University Press. 
Andreasen, A. R. (1975). The disadvantaged consumer. New York: The Free Press.

Andrews, D., \& Leigh, A. (2009). More inequality, less social mobility. Applied Economics Letters, 16(15),1489-1492.

Akula, V. (2011). A fistful of rice. United States of America: Harvard Business Review Press.

Babones, S. J. (2008). Income inequality and population health: Correlation and causality. Social Science \& Medicine, 66(7), 1614-1626.

Bales, K. (2004). Disposable people. New slavery in the global economy. Berkeley: University of California.

Bishop, M., \& Michael, G. (2008). Philanthro capitalism: How the rich can save the world. New York: Bloombury Press.

Casal, P. (2004). Justice across cultures. In M. Clayton., \& A. Williams (Eds.), Social justice (pp. 241-264). London: Blackwell.

Christensen, C. M. (1997). The innovator's dilemma. When new technologies cause great firms to fail. Boston: Harvard Business School.

Christensen, C. M. (2009).The innovator's prescription. A disruptive solution for health care. United States of America: McGraw-Hill.

Christensen, C. M., Mark W. J., \& Darrell, K. R.(2002). Foundations for growth: How to identify and build disruptive new business. MIT Sloan Management Review, 43(3), 22-23.

Christensen, C. M., Heiner B., Rudy, R., \& Thomas, M. S. (2006). Disruptive innovation for social change. Harvard Business Review, December, 94-103.

Cohen, G. A. (2004).The market: On the site of distributive justice. In M. Clayton., \& A. Williams (Eds.), Social justice (pp. 218-240). London: Blackwell.

Collier, P. (2008). The bottom billion: Why the poorest countries are failing and what can be done about it. London: Oxford University Press.

Hammond, A. L., \& Prahalad, C. K. (2004). Selling to the poor. Foreign Policy, 142, 30-37.

Hart, S. L. (2005). Capitalism at the cross roads. The unlimited business opportunities in solving the world's most difficult problems. New Jersey: Wharton School Publishing.

Hart, S. L., \& Christensen, C. M. (2002). The great leap driving innovation from the base of the pyramid. MIT Sloan Management Review, 44(1), 51-56.

Herberg, G. H. (1996). The religion of the Americans: In American culture. In A. Briedlid., F. C. Brogger., O. T. Gullicksen., \& T. Sirevag (Eds.), An anthology of civilization texts (pp. 245-250). New York: Routledge. 
Immelt, J. R., Govindarajan, V., \& Trimble, C. ( 2009). How GE is disrupting itself. Harvard Business Review, 87, 3-10.

London T., \& Hart, S. L.(2004). Reinventing strategies for emerging markets. Beyond the transactional model. Journal of International Business Studies, 35(5), 350-370.

Mascarenhas, O. A., Kesavan, R., \& Bernacchi, M. (2008). Buyerseller information asymmetry. Challenges to distributive and corrective justice. Journal of Macromarketing, 28(1), 68-84.

Mascarenhas, O. A., Kesavan, R., \& Bernacchi, M. (2005). Global marketing of lifesaving drugs: An analogical model. Journal of Consumer Marketing, 22, 404-411.

Maxwell, S. (1999). The meaning and measurement of poverty. ODI policy briefings. London: Overseas Development Institute.

Naim, M. (2007). Illicit: How smugglers, traffickers and copycats are hijacking the global economy. New York: Anchor Books.

Neumeier, M. (2008). The designful company. How to build a culture of nonstop innovation. New Jersey, USA: Peachpit Press.

Nicolas, A. D. (2010). Universality and learned ministry: Challenges to jesuit higher education today. Address to the networking jesuit higher education: Shaping the future of a humane, just sustainable globe conference. Mexico: Mexico City.

Nozick, R. A. (1977). State and Utopia. New York: Basic Books.

Okin, S. M. (1991). Justice, gender and the family. New York: Basic Books.

O'Neill, O.(1986). Faces of hunger: An essay on poverty, justice and development. New York: Harper Collins.

Pogge, T. W.(2004). Justice across borders. Brief for a global resources dividend. In M. Clayton., \& A. Williams (Eds.), Social justice (pp. 248-265). London: Blackwell.

Prahalad, C. K. (2009). The fortune at the bottom of the pyramid: Eradicating poverty through profits. New Jersey: Pearson Education.

Prahalad, C. K., \& Hart, S. L. (2002). Strategy + Business. The fortune at the bottom of the pyramid, 26, 2-14.

Prahalad, C. K., \& Hammond, A. (2002). Serving the world's poor, profitably. Harvard Business Review, 80(9), 48-57.

Prahalad, C. K. (2011). Bottom of the pyramid as a source of breakthrough innovations. Journal of Product Innovation Management, 29(1), 6-12.

Rawls, J. (2001). Justice as fairness. A restatement. Cambridge, MA: Harvard University Press.

Rittel, H., \& Webber, M. (1973). Dilemmas in a general theory of planning. Policy Sciences, 4, 155-169.

Rodriguez, O. A. (2006). The challenges of globalization for the church. A Latin American Perspective. Theology Digest, 53(1),13-23. 
Sachs, J. (2006). The end of poverty. New York: Penguin.

Sachs, J. (2008). Human rights. Journal of the section of individual rights \& responsibilities. Ending Poverty in Our Time, 32(3), $17-21$.

Scott, L., Williams, J. D., Baker, S. M., Brace, G. J., Downey, H., Hakstian, A. M., Henderson, G. R., Loroz, P. S., \& Webb, D. J. (2011) Beyond poverty: Social justice in a global marketplace. Journal of Public Policy \& Marketing, 30(1), 39-46.

Sen, A. (2000). Development as freedom. New York: Anchor Books.

Sen, A. (2011). The idea of justice. United States of America: The Penguin Press.

Senge, P. M. (2006). The fifth discipline: The art and practice of the learning organization revised edition. New York: Doubleday.

Sheth, J. N. (2011). Impact of emerging markets on marketing. Rethinking existing perspectives and practices. Journal of Marketing, 75(4), 166-182.

Sobhan, R. (2005). A macro policy for poverty eradication through structural change. The World Institute for Development Economics Research (WIDER)(1-13).United Nations University (UNU), Helsinki, Finland.

Sterman, J. (2010). Does formal system dynamics training improves people's understanding of accumulation? System Dynamics Review, 26(4), 316-334.

Subramanian, S. V., \& Kawachi, I. (2003). Response: In defense of the income inequality hypothesis. International Journal of Epidemiology, 32(6), 1037-1040.

Wilkinson, R. G., \& Pickett, K. E. (2006). Income inequality and population healthy: A review and explanation of evidence. Social Science \& Medicine, 66(7), 1768-1784.

Yunus, M. (2007). Creating a world without poverty. Social business and the future of capitalism. New York: Public Affair Books. 